\title{
Therapeutic potential of stem cell-derived extracellular vesicles in osteoarthritis: preclinical study findings
}

\author{
Ki Hoon Kim ${ }^{1}$, Jeong Hyun Jo ${ }^{1}$, Hye Jin Cho ${ }^{2}$, Tae Sub Park ${ }^{1,2}$ and Tae Min Kim ${ }^{1,2^{*}}$
}

\begin{abstract}
Extracellular vesicles (EVs) are nano-sized particles secreted by almost all cell types, and they mediate various biological processes via cell-to-cell communication. Compared with parental cells for therapeutic purposes, stem cell-derived EVs have several advantages such as reduced risk of rejection, less oncogenic potential, ease of longterm storage, lower chance of thromboembolism, and readiness for immediate use. Recent studies have demonstrated that EVs from stem cells, mostly from mesenchymal stem cells (MSCs) from various tissues, have antiinflammatory, anti-oxidative, anti-apoptotic, and proliferative role in injured organs including osteoarthritic lesions. Herein, we provide a review about the up-to-date studies in preclinical application of stem cell-derived EVs in osteoarthritis animal arthritis models.
\end{abstract}

Keywords: EVs (extracellular vesicles), MSCs (Mesenchymal stem cells), OA (osteoarthritis)

\section{Introduction}

Among joint diseases, osteoarthritis (OA) is one of the most severe types of arthritis that is caused by loss of joint cartilage and bone [1]. Mostly, the articular damage is due to loss of self-repair capability of injured cartilage caused by mechanical stress, e.g., sudden or unadjusted movements, mechanical injury, excess weight, loss of muscle strength supporting joint, and damage in peripheral nerves [2]. Also, it is still under debate whether exercise increases the risk of osteoarthritis in the knee [3].

\section{Osteoarthritis: its pathophysiology}

So far various soluble mediators have been reported to be involved in the progression of OA. Readers are referred to other reviews on the detailed role of the role of pro-inflammatory (IL-1 $\beta$, TNF- $\alpha$, IL-6, IL-17) (Fig. 1)

\footnotetext{
* Correspondence: taemin21@snu.ac.kr

${ }^{1}$ Graduate School of International Agricultural Technology, Pyeongchang, South Korea

${ }^{2}$ Institutes of Green-Bio Science and Technology, Seoul National University, Pyeongchang, Gangwon-do 25354, South Korea
}

and anti-inflammatory cytokines that are involved in OA pathogenesis (IL-4, IL-10, IL-13) $[4,5]$. For example, an elevated level of IL-1 $\beta$ and TNF- $\alpha$ was found in OA synovial fluid, synovial membrane, and subchondral bone cartilage [6]. Mechanistically, these cytokines down-regulated the synthesis extracellular matrix (ECM) component by inhibiting anabolic activities of chondrocytes. Another study showed that IL-1 $\beta$ reduces the expression of the type II collagen, which is a major ECM component constituting the cartilaginous tissues in several animal species [7, 8]. Also, the expression of Aggrecan, which is one of the major components of the cartilage, was found to be decreased by IL- $1 \beta$ treatment in chondrocytes and cartilage [9]. Indirectly, IL-1 $\beta$ and TNF- $\alpha$ stimulate chondrocyte to produce a proteolytic enzyme such as matrix metalloproteinases (MMPs), including MMP-1 (interstitial collagenase), MMP-3 (stromelysin 1), MMP-13 (collagenase 3) [10-12]. In addition, ADAMTS (a disintegrin-like and metalloproteinase with thrombospondin motifs) of is also one of the major players in cartilage degradation in OA. It was 


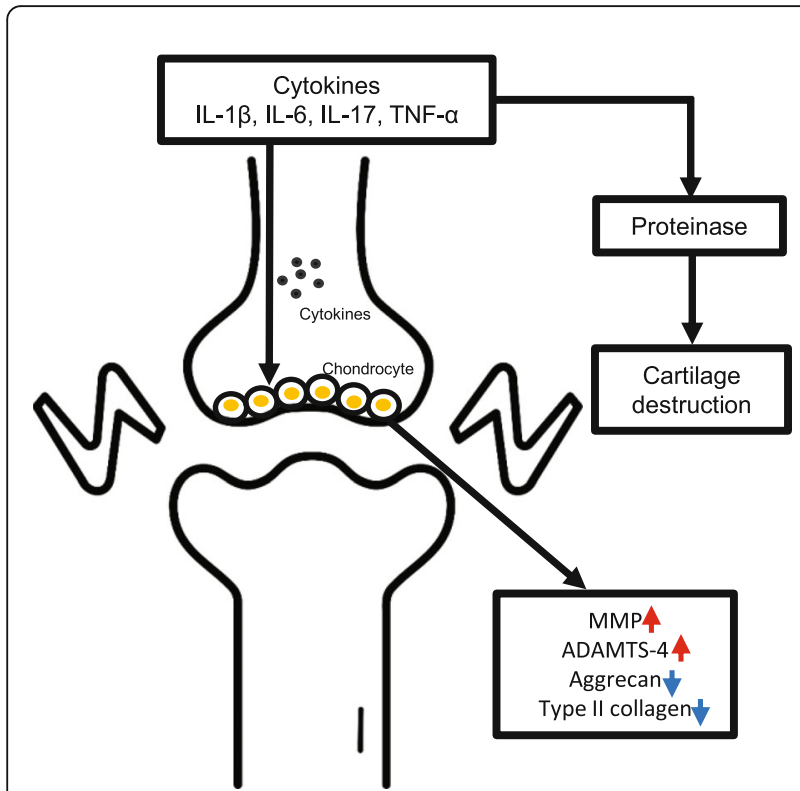

\title{
Osteoarthritis related-cytokines
}

\author{
IL-1 $\beta$, TNF- $\alpha$
}

Suppresses type II collagen and aggrecan expression

Stimulates the release of MMP-1, MMP-3 and MMP-13

Induces the production of IL- 6 and chemokines

IL-6

Upregulates MMP-1 and MMP-13

IL-17

Induces IL-1 $\beta$, TNF- $\alpha$, IL-6

Upregulates NO and MMPs

Downregulates proteoglycan

Fig. 1 The role of proinflammatory cytokines in the pathophysiology of OA. The role of proinflammatory cytokines, including IL-1 $\beta$, TNF-a, IL-6 and IL-17, are elevated in OA. These cytokines contribute to the pathogenesis of OA through several mechanisms including downregulation and upregulation of inflammatory responses. Abbreviations: ADAMTS: a disintegrin-like and metalloproteinase with thrombospondin motifs; IL: interleukin; MMP: matrix metalloproteinase; NO: nitric oxide; TNF: tumor necrosis factor

reported that the expression of ADAMTS-4 can be induced by IL- $1 \beta$ and TNF- $\alpha$, while the expression of ADAMTS-5 was not affected [13]. In contrast, subsequent study has shown that IL-1 $\beta$ induced its mRNA expression in rabbit nucleus [14]. Other than these proteases, miR30a was also shown to play an important role in controlling ADAMTS-5 expression that was caused by IL- $1 \beta[15]$. Also, IL- $1 \beta$ and TNF- $\alpha$ induce the generation of inflammatory cytokines such as IL-6 [14] and IL-8 [16], monocyte chemoattractant protein 1 (MCP1) [17] and CC-chemokine ligand 5 (CCL5) [18], all of which are well-reported players in sustaining tissue inflammation. IL-6 exists at a low concentration level in normal chondrocyte. However, its concentration in sera and chondrocytes is increased in osteoarthritic condition, after which it causes the increases in IL- $1 \beta$ and TGF- $\beta$, which in turn they promoted the production of IL-6 $[19,20]$. Studies also demonstrated that IL-6 stimulates the expression of MMP-1 and MMP-13 in bovine and humans (cell type) [21, 22], and IL-6 reduced the expression of type II collagen (cell type) [23]. Other studies showed that the expression of IL-17 is upregulated by IL-1 $\beta$, TNF- $\alpha$ and IL-6, after which IL-17 upregulated NO and MMPs production [24]. In addition, IL-17 led to a reduced expression of proteoglycan [25].

\section{Current treatment method for OA}

Depending on the disease status, clinical protocols can be classified into surgical method, using NSAIDs (Nonsteroidal anti-inflammatory drugs), via physical therapy, opioids, or intra-articular injection of hyaluronic acid (Fig. 2). Although NSAIDs have been commonly used for relieving inflammation due to their analgesic and anti-inflammatory effect, side effects such as the organ toxicity (e.g., liver and kidney) have been critical. In particular, using NSAIDs for a long-term or repeated time can lead to gastrointestinal tract hemorrhage [26-28]. Thus, other alternatives, i.e., cellular therapies using autologous or allogenic origins are now becoming recognized as save and effective option. Also, application of induced pluripotent stem cell (iPSC)-derived chondrocytes may be another choice depending on the regulation and safety guidelines [29]. Although several protocols are currently available for clinical purposes [30], cell-based therapy inherently possess the risk of immune rejection and tumor formation in vivo [31, 32]. Accordingly, application of extracellular vesicles, which can be obtained from desired cell types during culture, would be an ideal cell-free strategy that can solve the problems that can be raised upon implementing cell therapy [29, 33, 34].

\section{Isolation methods of EVs}

Currently, various protocols are being used to isolate EVs. Classically, ultracentrifugation is recognized as the most standardized method for isolating a large scale of EVs. Other methods include immunoaffinity isolation (magnetic bead isolation), tangential flow filtration, size exclusion chromatography, and polymer precipitation [35-38]. Ultracentrifugation can be modified or further 


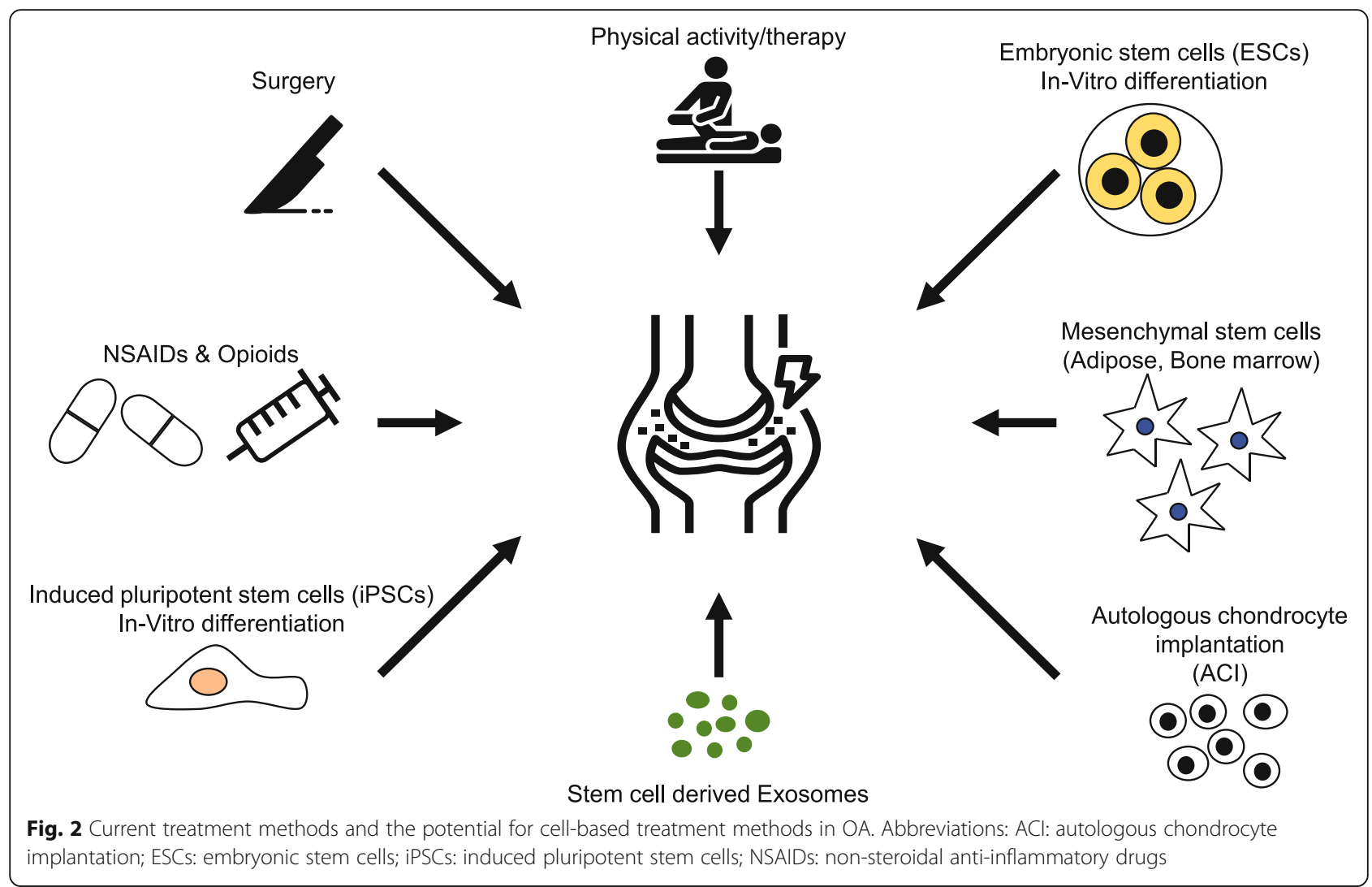

optimized, such as applying density gradient force during ultracentrifugation for harvesting EVs with an enhanced purity. To obtain EVs with higher purity in a large amount, tangential flow filtration method has been developed. This technique enables the removal of cell debris and unnecessary biomolecules by filtering the cell culture supernatant using sterile hollow fiber polyethersulfone membrane [39]. This system may be ideal for producing in an industrial (20-50 l) or laboratory scale (e.g.,300 ml) [37, 40]. Size exclusion (chromatography) method is based on physical barriers, for example filters or chromatographs. Ideally, this technique enables removing many contaminating elements such as albumin or lipoproteins. Depending on the size of EVs that are of interest, a range of different pore sizes $(0.8$ or $0.2 \mu \mathrm{m})$ may be used [41, 42]. Finally, polymeric precipitation method is relatively easy and quick, and optimal for enriching EVs for small-scale experimental purposes. Precipitation mixtures are incubated with culture medium, and low speed centrifugation is used to concentrate EVs [43]. There is, however, a study showing the quality of RNA extracted from polymeric precipitation may not be optimal [44].

\section{Characterization of EVs}

EVs are collective term for heterogeneous nano-sized lipid-bilayerd membrane vesicles having $30-2000 \mathrm{~nm}$ diameter. Importantly, EVs play essential role in intercellular communications due to a large variety of biologically active signaling molecules within EVs, including RNA species (messenger RNA and small RNA), proteins, enzymes, lipids and DNA fragments [45]. So far various characterization methods are available. TEM (Transmission electron microscopy) and SEM (Scanning electron microscopy) are usually used for verifying their cup- or round- shape [46-49]. TEM is more commonly used than SEM [50, 51]. The diameter size as well as their size distribution can be measured by NTA (nanoparticle tracking analyzer) $[49,52]$. Finally, the presence of EVspecific markers (CD9. CD63, CD81, TSG101, and Alix) $[48,49]$ can be examined by immunoblotting or flow cytometry.

\section{Preclinical studies}

EVs contain a wide spectrum of biomolecules including proteins, lipids, nucleic acids (DNAs, RNAs, small RNAs). Together with the notion that EVs are a natural player of cell-cell interaction in multicellular organisms, studies have focused on strengthening their specific function [53]. For example, miR-140-5p-overexpressing synovial MSCderived exosomes led to an enhancement of chondrocyte proliferation and migration, and prevented OA in a medial meniscus OA rat model [54]. Other study showed that human embryonic MSC-derived exosomes injected in medial 


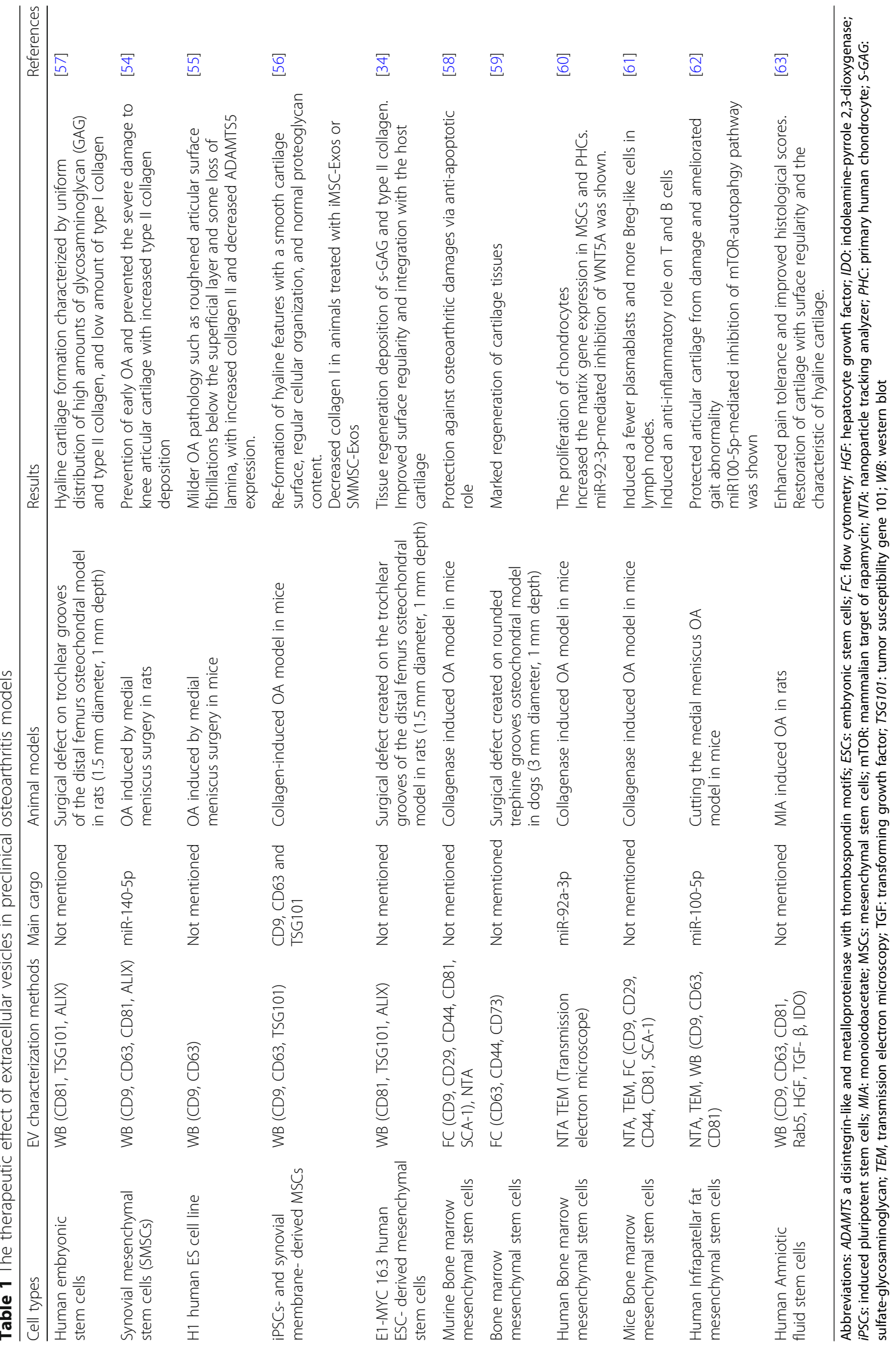


meniscus OA mouse model improved the synthesis of cartilage regeneration [55]. Another study compared the therapeutic efficacy between EVs from iPSC derived mesenchymal stem-like cells and synovial membranederived MSC in Collagenase-induced mouse OA model, and showed that EVs from iPSC derived MSC was better in reducing OA progression [56]. Similarly, in a rat model of osteochondral defect, EVs derived from human embryonic mesenchymal stems was able to reduce the disease progression [57]. Several mechanistic studies also showed that EVs from MSCs mediate cartilage repair by enhancing proliferation, attenuating apoptosis, modulating immune reactivity. For example, treatment of MSC-derived exosomes led to an enhanced activity of AKT and ERK signaling in cultured chondrocytes in vitro, and an increased infiltration of CD163+ regenerative M2 macrophages over CD86+ M1 macrophages was found in the osteochondral tissue in Surgical defect created on the model [34]. In addition, EVs from mouse BM-MSCs showed a therapeutic effect in collagenase induced arthritis model, as shown by Protection from osteoarthritis damage and a reduction of apoptotic cells injected in mouse chondrocyte, with a significant improvement cartilage generation. Finally, EV treatment was able to reduce osteophyte formation in a mice model of OA [58]. In an OA model created by making a rounded trephine grooves osteochondral model in dogs $(3 \mathrm{~mm}$ diameter, $1 \mathrm{~mm}$ depth), administration of mouse bone marrow MSCderived EV led to a marked regeneration of cartilage and restoration of chondral tissue [59]. Also, it was shown that WNT5A expression was inhibited by miR-92a-3p delivery by exosomes, which led to an inhibition of cartilage degradation [60]. In a collagenase induced arthritis model in mice, EVs from mouse BM-MSCs inhibited T lymphocyte proliferation in a dose-dependent manner, and also decreased the percentages of CD4 and CD8 subsets. Also, fewer plasmablasts and more Breg-like cell in lymph nodes was found [61].

miRNAs are one of the major biological cargoes in EVs from parental cells, and it was shown that miR-100$5 p$ was enriched in the exosomes derived from human Infrapatellar fat mesenchymal stem cells. Upon being injected intra-articular into OA mice induced by destabilization of the medial meniscus, the OA progression was dramatically attenuated, as shown by the reduction of articular damage and amelioration of gait abnormality. Molecular study also demonstrated that miR-100-5p inhibited mTOR/ autophagy pathway [62]. Another study demonstrated that exosomes from miR92a-3p-overexpressing BM-MSCs was able to promote the chondrocyte proliferation, and upregulated several matrix genes (Aggrecan, Col2A1, Sox9) and decreased a subset of other matrix genes (Col2A10, Runx2, MMP13, Wnt5A).
Another study showed that EVs from human amniotic fluid stem cells has therapeutic effect in MIA (Monoiodoacetate)-induced OA model in rats, as demonstrated by an enhanced pain tolerance and improved histological score. After 3 weeks of EV treatment, rat cartilage restoration with good surface regularity and with the characteristic of hyaline cartilage was shown. Moreover, markers of resolving marcrophages (CD163, arginase 1, and TGF $\beta$ ) were significantly increased after EV treatment [63].

Collectively, EVs from various stem cells alleviated the disease progression, as supported by results of tissue histology as well as inflammatory cytokine profiles in various preclinical OA models. We have provided a detailed list of studies that have attempted to use EVs from various parental cell types in OA animal models (Table 1).

\section{Conclusion}

EV carry out many different functions in organisms that include repair of tissue injuries, regulation of immune response, and inhibition of inflammation. The improvement in arthritic pathologies by MSCs is mostly due to cell-to-cell direct interaction and also by secretion of various soluble mediators. This review has presented MSC derived EVs as a cell-free treatment of joint damage and OA. It is currently accepted that the biological contents of EVs may significantly differ from those from parental cells, thus more extensive characterization of the membrane bound or luminal cargoes needed to further application of these unique nano-sized particles for therapeutic uses.

\section{Abbreviations \\ ACl: Autologous chondrocyte implantation; ADAMTS: A disintegrin-like and metalloproteinase with thrombospondin motifs; BM: Bone marrow; CCL5: CC- chemokine ligand 5; CD: Cluster of differentiation; Col2A1: Collagen type II alpha 2; Col2A10: Collagen type II alpha 10; ECM: Extracellular matrix; ESCs: Embryonic stem cells; EVs: Extracellular vesicles; FC: Flow cytometry; HGF: Hepatocyte growth factor; IDO: Indoleamine-pyrrole 2,3-dioxygenase; IL: Interleukin; iPSCs: Induced pluripotent stem cells; MCP1: Monocyte chemoattractant protein 1; MIA: Monoiodoacetate; MMP: Matrix metalloproteinase; MSCs: Mesenchymal stem cells; mTOR: Mammalian target of rapamycin; NO: Nitric oxide; NSAIDs: Non-steroidal anti-inflammatory drugs; NTA: Nanoparticle tracking analyzer; OA: Osteoarthritis; PHC: Primary human chondrocyte; Runx2: Runt-related transcription factor 2; SEM: Scanning electron microscopy; S-GAG: Sulfate-glycosaminoglycan; TEM: Transmission electron microscopy; TGF: Transforming growth factor; TNF: Tumor necrosis factor; TSG101: Tumor susceptibility gene 101; WB: Western blot}

\section{Acknowledgments}

This work was supported by Research Resettlement Fund for the new faculty of Seoul National University.

\section{Authors' contributions}

KHK, JHJ, HJC, TSP and TMK wrote this review. TMK provided the general concepts and organized this manuscript. The author (s) read and approved the final manuscript. 


\section{Funding}

This work was also supported by Basic Science Research Program through the National Research Foundation of Korea (NRF) funded by the Ministry of Education (2018R1D1A1A02085481) (T.M.K)

\section{Availability of data and materials}

Not applicable.

\section{Competing interests}

The authors declare that they have no competing interests.

\section{Received: 14 January 2020 Accepted: 23 March 2020}

Published online: 15 April 2020

\section{References}

1. Goldring MB, Ostero M. Inflammation in osteoarthtitis. Curr Opin Reumatol. 2011;23(5):471-8.

2. Kenneth D, Brandt MD, Paul Dieppe MD, Radin MD EL. Etiopathogenesis of osteoarthritis. Rheum Dis Clin N Am. 2008:34(3):531-59.

3. Bosomworth NJ. Exercise and knee osteoarthritis: benefit or hazard? Can Fam Physician. 2009:55(9):871-8.

4. Femandes JC, Martel-Pelletier J, Pelletier JP. The role of cytokine in osteoarthtitis pathophysiology. Biorheology. 2002;39(1-2):237-46.

5. Kapoor M, Martel-Pelletier J, Lajeunesse D, Pelletier JP, Fahmi H. Role of proinflammatory cytokines in the pathophysiology of osteoarthritis. Nat Rev Rheumatol. 2011;7(1):33-42.

6. Hollander JL. Arthritis and allied conditions. Textbook Rheumatol J Med Educ. 1960;35(10):988.

7. Chadjichristos C, Ghayor C, Kypriotou M, Martin G, Renard E, Ala-Kokko L, Suske G, de Crombrugghe B, Pujol JP, Galéra P. Sp1 and Sp3 transcription factors mediate interleukin-1 beta down-regulation of human type II collagen gene expression in articular chondrocytes. J Biol Chem. 2003; 278(41):39762-72.

8. Shakibaei M, Schulze-Tanzil G, John T, Mobasheri A. Curcumin protects human chondrocytes from IL-11 beta-induced inhibition of collagen type II and beta1-integrin expression and activation of caspase-3: an immunomorphological study. Ann Anat. 2005;187(5-6):487-97.

9. Nietfeld JJ, Wilbrink B, Den Otter W, Huber J, Huber-Bruning O. The effect of human interleukin 1 on proteoglycan metabolism in human and porcine cartilage explants. J Rheumatol. 1990;17(6):818-26.

10. Mengshol JA, Vincenti MP, Coon Cl, Barchowsky A, Brinckerhoff CE. Interleukin-1 induction of collagenase 3 (matrix metalloproteinase 13) gene expression in chondrocytes requires p38, c-Jun N-terminal kinase, and nuclear factor kappaB: differential regulation of collagenase 1 and collagenase 3. Arthritis Rheum. 2000;43(3):801-11.

11. Lefebvre V, Peeters-Joris C, Vaes G. Modulation by interleukin 1 and tumor necrosis factor alpha of production of collagenase, tissue inhibitor of metalloproteinases and collagen types in differentiated and dedifferentiated articular chondrocytes. Biochim Biophys Acta. 1990;1052(3):366-78.

12. Reboul P, Pelletier JP, Tardif G, Cloutier JM, Martel-Pelletier J. The new collagenase, collagenase- 3 , is expressed and synthesized by human chondrocytes but not by synoviocytes. A role in osteoarthritis. J Clin Invest. 1996;97(9):2011-9.

13. Tortorella MD, Malfait AM, Deccico C, Arner E. The role of ADAM-TS4 (aggrecanase-1) and ADAM-TS5 (aggrecanase-2) in a model of cartilage degradation. Osteoarthr Cartil. 2001;9(6):539-52.

14. Seki S, Asanuma-Abe Y, Masuda K, Kawaguchi Y, Asanuma K, Muehleman C, Iwai A, Kimura T. Effect of small interference RNA (siRNA) for ADAMTS5 on intervertebral disc degeneration in the rabbit anular needle-puncture model. Arthritis Res Ther. 2009;11(6):R166.

15. Ji Q, Xu X, Zhang Q, Kang L, Xu Y, Zhang K, Li L, Liang Y, Hong T, Ye Q, Wang $Y$. The IL-1 $\beta / A P-1 / m i R-30 a / A D A M T S-5$ axis regulates cartilage matrix degradation in human osteoarthritis. J Mol Med (Berl). 2016 Jul;94(7):771-85.

16. Lotz M, Terkeltaub R, Villiger PM. Cartilage and joint inflammation. Regulation of IL-8 expression by human articular chondrocytes. J Immunol. 1992;148(2):466-73.

17. Villiger PM, Terkeltaub R, Lotz M. Monocyte chemoattractant protein-1 (MCP-1) expression in human articular cartilage. Induction by peptide regulatory factors and differential effects of dexamethasone and retinoic acid. J Clin Invest. 1992;90(2):488-96.
18. Alaaeddine N, Olee T, Hashimoto S, Creighton-Achermann L, Lotz M. Production of the chemokine RANTES by articular chondrocytes and role in cartilage degradation. Arthritis Rheum. 2001;44(7):1633-43.

19. Guerne PA, Carson DA, Lotz M. IL-6 production by human articular chondrocytes. Modulation of its synthesis by cytokines, growth factors, and hormones in vitro. J Immunol. 1990;144(2):499-505.

20. Bender S, Haubeck HD, Van de Leur E, Dufhues G, Schiel X, Lauwerijns J, Greiling $\mathrm{H}$, Heinrich PC. Interleukin-1 beta induces synthesis and secretion of interleukin-6 in human chondrocytes. FEBS Lett. 1990;263(2):321-4.

21. Cawston TE, Curry VA, Summers CA, Clark IM, Riley GP, Life PF, Spaull JR, Goldring MB, Koshy PJ, Rowan AD, Shingleton WD. The role of oncostatin M in animal and human connective tissue collagen turnover and its localization within the rheumatoid joint. Arthritis Rheum. 1998;41(10):1760-71.

22. Rowan AD, Koshy PJ, Shingleton WD, Degnan BA, Heath JK, Vernallis AB, Spaull JR, Life PF, Hudson K, Cawston TE. Synergistic effects of glycoprotein 130 binding cytokines in combination with interleukin-1 on cartilage collagen breakdown. Arthritis Rheum. 2001;44(7):1620-32.

23. Porée B, Kypriotou M, Chadjichristos C, Beauchef $G$, Renard E, Legendre F, Melin M, Gueret S, Hartmann DJ, Malléin-Gerin F, Pujol JP, Boumediene K, Galéra P. Interleukin-6 (IL-6) and/or soluble IL-6 receptor down-regulation of human type II collagen gene expression in articular chondrocytes requires a decrease of Sp1.Sp3 ratio and of the binding activity of both factors to the COL2A1 promoter. J Biol Chem. 2008;283(8):4850-65.

24. Martel-Pelletier J, Mineau F, Jovanovic D, Di Battista JA, Pelletier JP. Mitogenactivated protein kinase and nuclear factor kappaB together regulate interleukin17-induced nitric oxide production in human osteoarthritic chondrocytes: possible role of transactivating factor mitogen-activated protein kinase-activated proten kinase (MAPKAPK). Arthritis Rheum. 1999:42(11):2399-409.

25. Lubberts $E$, Joosten LA, van de Loo FA, van den Gersselaar LA, van den Berg WB. Reduction of interleukin-17-induced inhibition of chondrocyte proteoglycan synthesis in intact murine articular cartilage by interleukin-4. Arthritis Rheum. 2000;43(6):1300-6.

26. Singh G, Rosen RD. NSAID induced gastrointestinal complications: the ARAMIS perspective--1997. Arthritis, rheumatism, and aging medical information system. J Rheumatol Suppl. 1998;51:8-16.

27. Schaffer D, Florin T, Eagle C, Marschner I, Singh G, Grobler M, Fenn C, Schou M, Curnow KM. Risk of serious NSAID-related gastrointestinal events during long-term exposure: a systematic review. Med J Aust. 2006;185(9):501-6.

28. Laine L. Gl risk and risk factors of NSAIDs. J Cardiovasc Pharmacol. 2006; 47(Suppl 1):S60-6.

29. Burke J, Hunter M, Kolhe R, Isales C, Hamrick M, Fulzele S. Therapeutic potential of mesenchymal stem cell based therapy for osteoarthritis. Clin Transl Med. 2016:5(1):27.

30. Schurman DJ, Smith RL. Osteoarthritis: current treatment and future prospects for surgical, medical, and biologic intervention. Clin Orthop Relat Res. 2004;(427 Suppl):S183-9.

31. Pers YM, Ruiz M, Noël $D$, Jorgensen C. Mesenchymal stem cells for the management of inflammation in osteoarthritis: state of the art and perspectives. Osteoarthr Cartil. 2015:23(11):2027-35.

32. Karnoub AE, Dash AB, Vo AP, Sullivan A, Brooks MW, Bell GW, Richardson AL, Polyak K, Tubo R, Weinberg RA. Mesenchymal stem cells within tumour stroma promote breast cancer metastasis. Nature. 2007:449(7162):557-63.

33. Toh WS, Lai RC, Hui JHP, Lim SK. MSC exosome as a cell-free MSC therapy for cartilage regeneration: implications for osteoarthritis treatment. Semin Cell Dev Biol. 2017:67:56-64.

34. Zhang S, Chuah SJ, Lai RC, Hui JHP, Lim SK, Toh WS. MSC exosomes mediate cartilage repair by enhancing proliferation, attenuating apoptosis and modulating immune reactivity. Biomaterials. 2018;156:16-27.

35. Witwer KW, Buzás El, Bemis LT, Bora A, Lässer C, Lötvall J, Nolte-'t Hoen EN, Piper MG, et al. Standardization of sample collection, isolation and analysis methods in extracellular vesicle research. J Extracell Vesicles. 2013;2(1). https://doi.org/10.3402/jev.v2i0.20360.

36. Reiner AT, Witwer KW, van Balkom BWM, de Beer J, Brodie C, Corteling RL, et al. Concise Review: Developing best-practice models for the therapeutic use of extracellular vesicles stem cells. Transl Med. 2017;6(8):1730-9.

37. Haraszti RA, Miller R, Stoppato M, Sere YY, Coles A, Didiot MC, Wollacott R, et al. Exosomes produced from 3D cultures of MSCs by tangential flow filtration show higher yield and improved activity. Mol Ther. 2018;26(12):2838-47.

38. Wu JY, Ji AL, Wang ZX, Qiang GH, Qu Z, Wu JH, Jiang CP. Exosome-mimetic nanovesicles from hepatocytes promote hepatocyte proliferation in vitro and liver regeneration in vivo. Sci Rep. 2018;8(1):2471. 
39. Busatto S, Vilanilam G, Ticer T, Lin WL, Dickson DW, Shapiro S, Bergese P, Wolfram J. Tangential flow filtration for highly efficient concentration of extracellular vesicles from large volumes of fluid. Cells. 2018;7(12). https:// doi.org/10.3390/cells7120273.

40. Vishnubhatla I, Corteling R, Stevanato L, Hicks C, Sinden J. The development of stem cell-derived exosomes as a cell-free regenerative medicine. J Circ Biomark. 2014;3(2). https://doi.org/10.5772/58597.

41. György B, Módos K, Pállinger E, Pálóczi K, Pásztói M, Misják P, Deli MA, Sipos A, Szalai A, et al. Detection and isolation of cell-derived microparticles are compromised by protein complexes resulting from shared biophysical parameters. Blood. 2011;117(4):e39-48.

42. Théry C, Amigorena S, Raposo G, Clayton A. Isolation and characterization of exosomes from cell culture supernatants and biological fluids. Curr Protoc Cell Biol. 2006;30(1). https://doi.org/10.1002/0471143030.cb0322s30.

43. Alvarez ML, Khosroheidari M, Kanchi Ravi R, DiStefano JK. Comparison of protein, microRNA, and mRNA yields using different methods of urinary exosome isolation for the discovery of kidney disease biomarkers. Kidney Int. 2012;82(9):1024-32

44. Taylor DD, Zacharias W, Gercel-Taylor C. Exosome isolation for proteomic analyses and RNA profiling. Methods Mol Biol. 2011;728:235-46.

45. Lamichhane TN, Sokic S, Schardt JS, Raiker RS, Lin JW, Jay SM. Emerging roles for extracellular vesicles in tissue engineering and regenerative medicine. Tissue Eng Part B Rev. 2014;21(1):45-54.

46. Chernyshev VS, Rachamadugu R, Tseng YH, Belnap DM, Jia Y, Branch KJ, Butterfield $A E$, et al. Size and shape characterization of hydrated and desiccated exosomes. Anal Bioanal Chem. 2015;407(12):3285-301.

47. György B, Szabó TG, Pásztói M, Pál Z, Misják P, Aradi B, László V, Pállinger E Pap E, Kittel A, et al. Membrane vesicles, current state-of-the-art: emerging role of extracellular vesicles. Cell Mol Life Sci. 2011;68(16):2667-88.

48. Li Z, Wang Y, Xiao K, Xiang S, Li Z, Weng X. Emerging role of exosomes in the joint diseases. Cell Physiol Biochem. 2018;47(5):2008-17.

49. Doyle LM, Wang MZ. Overview of extracellular vesicles, their origin, composition, purpose, and methods for exosome isolation and analysis. Cells. 2019;8(7). https://doi.org/10.3390/cells8070727.

50. Sokolova V, Ludwig AK, Hornung S, Rotan O, Horn PA, Epple M, Giebel B. Characterisation of exosomes derived from human cells by nanoparticle tracking analysis and scanning electron microscopy. Colloids Surf B Biointerfaces. 2011;87(1):146-50.

51. Sharma S, Rasool HI, Palanisamy V, Mathisen C, Schmidt M, Wong DT, Gimzewski JK. Structural-mechanical characterization of nanoparticle exosomes in human saliva, using correlative AFM, FESEM, and force spectroscopy. ACS Nano. 2010;4(4):1921-6.

52. Rupert DLM, Claudio V, Lässer C, Bally M. Methods for the physica characterization and quantification of extracellular vesicles in biological samples. Biochim Biophys Acta Gen Subj. 2017;1861(1 Pt A):3164-79.

53. Raposo G, Stoorvogel W. Extracellular vesicles: exosomes, microvesicles, and friends. J Cell Biol. 2013;200(4):373-83.

54. Tao SC, Yuan T, Zhang YL, Yin WJ, Guo SC, Zhang CQ. Exosomes derived from miR-140-5p-overexpressing human synovial mesenchymal stem cells enhance cartilage tissue regeneration and prevent osteoarthritis of the knee in a rat model. Theranostics. 2017;7(1):180-95.

55. Wang Y, Yu D, Liu Z, Zhou F, Dai J, Wu B, Zhou J, Heng BC, Zou XH, Ouyang $\mathrm{H}$, Liu $\mathrm{H}$. Exosomes from embryonic mesenchymal stem cells alleviate osteoarthritis through balancing synthesis and degradation of cartilage extracellular matrix. Stem Cell Res Ther. 2017:8(1):189.

56. Zhu Y, Wang Y, Zhao B, Niu X, Hu B, Li Q, Zhang J, Ding J, Chen Y, Wang Y. Comparison of exosomes secreted by induced pluripotent stem cell-derived mesenchymal stem cells and synovial membrane-derived mesenchymal stem cells for the treatment of osteoarthritis. Stem Cell Res Ther. 2017;8(1):64.

57. Zhang S, Chu WC, Lai RC, Lim SK, Hui JH, Toh WS. Exosomes derived from human embryonic mesenchymal stem cells promote osteochondral regeneration. Osteoarthr Cartil. 2016;24(12):2135-40.

58. Cosenza S, Ruiz M, Toupet K, Jorgensen C, Noël D. Mesenchymal stem cells derived exosomes and microparticles protect cartilage and bone from degradation in osteoarthritis. Sci Rep. 2017;7(1).

59. Sabry D, Shamaa A, Amer M, El-Tookhy O, Abdallah A, Abd El Hassib DM, et al. The effect of mesenchymal sCell derived microvesicles in repair of femoral chondral defects in dogs. J Musculoskelet Res. 2018;21(2). https:// doi.org/10.1142/S0218957718500069.

60. Mao G, Zhang Z, Hu S, Zhang Z, Chang Z, Huang Z, Liao W, Kang Y. Exosomes derived from miR-92a-3p-overexpressing human mesenchymal stem cells enhance chondrogenesis and suppress cartilage degradation via targeting WNT5A. Stem Cell Res Ther. 2018;9(1). https://doi.org/10.1186/ s13287-018-1004-0.

61. Cosenza S, Toupet K, Maumus M, Luz-Crawford P, Blanc-Brude O, Jorgensen C, Noël D. Mesenchymal stem cells-derived exosomes are more immunosuppressive than microparticles in inflammatory arthritis. Theranostics. 2018;8(5):1399-410.

62. Wu J, Kuang L, Chen C, Yang J, Zeng WN, Li T, Chen H, Huang S, Fu Z, Li J, et al. miR-100-5p-abundant exosomes derived from infrapatellar fat pad MSCs protect articular cartilage and ameliorate gait abnormalities via inhibition of mTOR in osteoarthritis. Biomaterials. 2019;206:87-100.

63. Zavatti M, Beretti F, Casciaro F, Bertucci E, Maraldi T. Comparison of the therapeutic effect of amniotic fluid stem cells and their exosomes on monoiodoacetate-induced animal model of osteoarthritis. Biofactors. 2019: $1-12$

\section{Publisher's Note}

Springer Nature remains neutral with regard to jurisdictional claims in published maps and institutional affiliations.

Ready to submit your research? Choose BMC and benefit from:

- fast, convenient online submission

- thorough peer review by experienced researchers in your field

- rapid publication on acceptance

- support for research data, including large and complex data types

- gold Open Access which fosters wider collaboration and increased citations

- maximum visibility for your research: over $100 \mathrm{M}$ website views per year

At $\mathrm{BMC}$, research is always in progress.

Learn more biomedcentral.com/submissions 